\title{
Expanding evaluation to progress strategic communication: Beyond message tracking to open listening
}

\author{
Jim Macnamara \\ University of Technology Sydney, Australia
}

Anne Gregory

University of Huddersfield, UK

\begin{abstract}
Management writer Tom Peters noted that what gets measured is what gets done in organizations. Therefore, measurement and evaluation models and approaches provide insights into strategy. Furthermore, the most widely used approaches to evaluation are based on program logic models that identify objectives, planning, and inputs, as well as seeking to track outputs, outcomes and impact, thus affording insights into the origins of strategy and strategic intent as well, as its implementation. Given increasing focus on emergent strategy and participatory or networked strategy in place of internally predetermined strategy that is unilaterally focussed on an organization' goals and objectives, this article critically reviews widely-used models for evaluation of communication to identify how well they support and enable broader contemporary approaches to organizational strategy and strategic communication. This analysis shows a narrow organization-centric focus on evaluating organizational messaging (oneway communication) directed at achieving organizational objectives in traditional evaluation models and calls for a more open, dynamic and expanded approach to facilitate two-way communication. Furthermore, in showing the important role of formative as well as summative evaluation, this analysis identifies a number of ways that evaluation of communication can inform organizational strategy and transform strategic communication.
\end{abstract}

Keywords: Strategic communication, strategy, objectives, interests, evaluation

\section{Introduction}

Evaluation models for communication might seem like an unlikely starting point for an analysis designed to inform and enable strategic communication. However, management writer Tom Peters $(1986)^{1}$ noted that what gets measured is what gets done in organizations. Therefore, measurement and evaluation models and approaches provide insights into strategy. Contemporary evaluation literature says that, beyond merely identifying what works, evaluation answers the question: 'what works, for whom, under what circumstances, and how?' (Better Evaluation, 2016, para. 2; Pawson \& Tilley (1997, p. 342; Pawson, 2006, 2013). Furthermore, the most widely used approaches to evaluation are based on program logic models that identify objectives, planning steps, and inputs, as well as seeking to track outputs, outcomes and impact, thus affording insights into the origins of strategy and strategic intent as well as its implementation. Therefore, popular evaluation models provide a useful site to study the development and implementation of organizational strategy and the role of strategic communication.

\section{Strategic communication theory}

There have been a number of moves over the past decade in both scholarship and practice to establish strategic communication as a distinct field of study as well as attempts to reconceptualize public relations, corporate communication, government communication, and other 
fields of practice as 'strategic communication'. In their seminal article published in the International Journal of Strategic Communication, Hallahan, Holtzhausen, van Ruler, Verčič, and Sriramesh (2007) noted that "strategic communication has been used synonymously for public relations" in much of the literature" (2007, p. 9). In Europe in particular, where the term 'public relations' is not widely used (Bentele, 2004; van Ruler \& Verčič, 2004), and in the public sector in several countries including the United Kingdom (UK) and European Union states, organization-public communication is increasingly referred to as strategic communication (Aarts, 2009; Aarts \& Van Woerkum, 2008).

However, the origin of the term 'strategic', which is derived from the Greek noun strategia meaning 'generalship', and its associations of military planning, victory, and conquest taint understandings of strategy and strategic communication. Twentieth century management literature associated 'strategic' with power and decision-making (Mintzberg, 1979), organizational survival and efficiency (Perrow, 1992), and being goal or "outcome focused" (Lukaszewski, 2001). As Hallahan et al. acknowledged, outcome focused strategic communication by an organization is widely understood as "purposeful use of communication to fulfil its [i.e., the organization's] mission” (2007, p. 3). In this view, stakeholders and publics are perceived as targets for persuasion and change in ways that serve the interests of the organization, not necessarily in ways that meet the needs or interests of stakeholders and publics, or their communities and society.

Building on the Hallahan et al. article and their own 2013 article (Holtzhausen \& Zerfass, 2013), Holtzhausen and Zerfass defined strategic communication in The Routledge Handbook of Strategic Communication as "the practice of deliberate and purposive communication that a communication agent enacts in the public sphere on behalf of a communicative entity to reach set goals” (2015, p. 4). This definition goes further than that of Hallahan et al., but it makes clear that strategic communication is conducted in the interests of "a communicative entity" and refers to "set" goals with no reference to stakeholders or publics, thus implying unilaterally predetermined goals. While achieving a communicative entity's goals could potentially include adapting or changing its behaviour rather than that of stakeholders or 'target audiences', this potential is not represented in the first step of evaluation models (setting communication objectives) or in referring to outcomes and impact, as will be discussed in this analysis.

Strategic communication is by nature and necessity closely linked to organizational strategy, as it takes place within the context of and often at the behest of organizational strategy, which in turn is grounded in systems theory as applied to management and concepts such as strategic control. Early definitions of strategic control proposed that (1) strategy was implemented as planned by the organization and (2) the results produced were those intended (Schendel \& Hofer, 1979, p. 18). In traditional management thinking, the level of strategic control was determined as part of feedback and review, which was the last step in the management process.

In their seminal article on strategy, Schreyoegg and Steinmann critiqued this traditional view as "inadequate" on two grounds (1987, p. 91). First, they observed that feedback often comes too late for changes to be made to strategy and, second, feedback as a last step in the management process involves a "single loop" (1987 p. 92). Describing strategic planning as "a succession of selective steps" (1987, p. 94), they noted that modern systems theory emphasizes that "the survival of a system requires a continuous process" of selecting strategies and review (1987, p. 93). Schreyoegg and Steinmann proposed a three-stage model for what they call "strategic control". This comprises (1) premise control, which involves checking that the premises set (or assumptions made) during planning remain valid; (2) implementation control, which involves monitoring whether implementation proceeds as planned; and (3) strategic surveillance, which 
is designed "to monitor the full range of events inside and outside the enterprise which are likely to threaten the course of strategic action” (1987, p. 97).

These three stages can be seen to broadly equate to the three types of evaluation: formative, process and summative (Valente, 2001), a multi-dimensional concept of evaluation well established in program evaluation literature and further discussed later in this analysis, but often ignored in PR and communication. Also, as Schreyoegg and Steinmann acknowledge, strategic control, particularly at the strategic surveillance stage, is similar to environmental scanning, which is recommended in program evaluation theory and PR and communication literature. These authors claim that there is a difference by assuming that environmental scanning is conducted only in the early stages of planning. However, there is no reason why environmental scanning cannot be conducted continuously and such an approach is proposed in the expanded dynamic process of evaluation recommended here.

The objective of Schreyoegg and Steinmann's concept of strategic control is to provide feedforward information, not only feedback - that is, learning and insights that can inform future strategic planning. Again, this is a central focus of contemporary evaluation research - albeit it is not reflected in current evaluation models for PR and strategic communication as will be shown.

Despite a broadening concept of strategy, the spectre of organization centricity continues to haunt the strategic communication field. For example, despite evolution of marketing communication from a short-term transactional focus on sales and profits (i.e., the organization's objectives), to relationship marketing (Berry, 1983) designed to create mutually rewarding relationships between organizations and their customers (Palmatier, 2008, pp. 1-2), Palmatier defines relationship marketing as "the process of identifying, developing, maintaining, and terminating relational exchanges with the purpose of enhancing performance” $(2008, p$. 3). It is clear that it is the performance of the organization that is the focus, particularly its financial performance. The interests of stakeholders or publics are little discussed in marketing communication literature other than as 'target audiences' and 'target markets'.

While marketing communication is seen by some as distinctly different to corporate and other forms of strategic communication (e.g., Cornelissen, 2011), other researchers point to similar paradoxes in business and government communication. For example, Schneider identifies the "rise of strategic communication" in government and public diplomacy with a primary focus on changing the attitudes and behaviour of target audiences (2015, p. 18). Drawing on leading contemporary management texts such as Thompson, Peteraf, Gamble, and Strickland (2013), Dulek and Campbell conclude that strategy in communication "focuses on achieving the sender's predetermined aim” (2015, p. 123). In their 2015 discussion titled 'On the dark side of strategic communication', Dulek and Campbell note that strategy "shifts the focus from context and the recipient to purpose and the sender” (2015, p. 123).

In their comprehensive edited text on strategic communication, Holtzhausen and Zerfass note in discussing the behavioural outcomes of strategic communication that there is "a cohesive focus on the behavioural outcomes of stakeholders" (2015, p.11). There is relatively little discussion of behavioural outcomes and responses to feedback within the organization - a gap that this analysis seeks to address in this important emerging field.

Contemporary management literature has further expanded understanding of strategy beyond Schreyoegg and Steinmann's notion of 'strategic control', introducing concepts such as emergent strategy, first proposed by Mintzberg (1978; Mintzberg \& Walters, 1985) and expanded recently by management scholars such as Mirabeau and Maguire (2014); participatory strategy, which 
operationalizes emergence through wide stakeholder engagement (Matzler, Füller, Hutter, Hautz, \& Stieger, 2014); and agility (Denning, 2016; Moran, 2015). Participatory strategy is now advocated in a wide range of sectors including health, international development, education, and project management. As well as advocating participatory strategy, Matzler et al. refer to new approaches as "democratizing strategy”, “open strategy” and "open-source strategy" and argue that social media can be used to inform organizational strategy (2014, p. 1). Organization agility refers to the capacity of an organization to adapt to its environment, ideally quickly, based on feedback and intelligence (Moran, 2015).

These management theories show the integral role of communication in organizational strategy, both in informing it and facilitating implementation. Also, they show that the notion of control is increasingly problematic, suggesting instead a dynamic interactive process of strategic planning and implementation. This is particularly the case in relation to communication and public relations practice. Here, of course, it must be said that understanding strategic communication hinges on one's understanding of communication. In contrast with basic systems theory approaches such as the Shannon and Weaver (1949) information transmission model that served early concepts of strategic communication, communication today is defined as a two-way interactive process involving speaking (verbally, textually or visually), listening, and responding (Craig, 2006; Littlejohn \& Foss, 2008). Communication is also informed by dialogic theory (Bakhtin, 1986; Buber, 1958) based on openness to and respect for others (Gadamer, 1989). As Holtzhausen and Zerfass acknowledge, "the notion that communication can be controlled and regulated is now largely redundant” (2015, p. 7). Recognition of communication as a two-way dynamic process designed to achieve understanding and mutuality through adaptation and accommodation further informs this analysis.

In summary, contemporary management literature extensively discusses how and why organizations need to change from a top-down 'command and control' approach in which senior management pre-determines strategy unilaterally inside the organization to one that involves strategic learning and is adaptive (e.g., Mirabeau \& Maguire, 2014). In public relations literature, van Ruler (2016) has referred to this as an agile approach to strategic communication.

Hallahan and colleagues mounted a concerted effort to redefine and rehabilitate the term 'strategic' within PR and communication theory. Arguing against Modernist approaches in management in which strategic communication "privileges a management discourse and emphasizes upper management's goals for the organization as given and legitimate” (2007, p. 11), they claimed that "alternative and more positive notions of strategy have ... emerged since the 1950s" that "reject the use of strategic only in an asymmetrical context" (p. 13).

Instead, Hallahan et al. argued that contemporary models of public relations are based on twoway transactional rather one-way transmissional models of communication. They claimed that these recognize and engage audiences in an inclusive 'win-win' process. In addition, they cited and supported Holtzhausen's (2005) view that strategic communication includes recognition that organizational survival means that organizations must adhere to the value systems of the environments in which they operate.

An emerging body of literature on strategic communication urges attention to stakeholder interests as well as the organization's interests. Drawing on Mintzberg's advocacy for emergent strategy in place of deliberate strategy (Mintzberg, 1978; Mintzberg \& Walters, 1985), King (2010, p. 19) recommended "emergent communication strategies". While acknowledging that communication strategy involves intentional planned actions by organizations to achieve desired results, she noted that strategies also emerge regardless of writer/speaker intent. She defined 
emergent communication strategies as "a communicative construct derived from interaction between reader/hearer response, situated context, and discursive patterns” (2010, p. 20).

In an ICA pre-conference on strategic communication in 2011 and subsequently in published journal articles and book chapters, a number of scholars called for a further reconceptualization of strategic communication to banish the spectre of organization-centricity that has haunted traditional approaches and contributed to the 'shadow' of public relations are related practices discussed by Fawkes (2015) by giving attention to stakeholders' and publics' interests. Falkheimer and Heide (2015) have called on scholars and practitioners to break the dominant approach to strategic communication, which has focused on control, persuasion, and organizational effectiveness and adopt a participatory approach. In a pragmatic compromise, Torp (2015) called for what he termed 'the strategic turn' to incorporate the duality that Deetz (1992) identified - openness to participation, while at the same time not abandoning the organizational imperative to represent and advocate its interests. Murphy (2015) proposed that a network view of strategic communication provides a holistic view of the opinion arena and recognizes the interconnected, fluid and participatory nature of this environment.

In corporate communication literature, Cornelissen says: "Strategy is about the organization and its environment" and that strategy involves "balancing the mission and vision of the organization ... with what the environment will allow or encourage it to do. Strategy is therefore often adaptive” (2011, p. 83).

The upcoming International Encyclopedia of Strategic Communication (Heath \& Johansen, forthcoming) is based on an argument that "a new approach has emerged" in which strategic communication is designed by organizations "to achieve outcomes that legitimately serve their interests and those they work to influence as well as collaborate with” (Wiley Blackwell, 2017, p. 4).

A decade on from Hallahan et al.'s landmark article and seven years since the 2011 ICA discussion, it is timely to review the concept and principles of strategic communication. A useful contribution to this process was provided by the 2017 ICA pre-conference on strategic communication, which this special issue draws together and seeks to build on. The following analysis of evaluation models, which represent and inform the process from planning and objective setting to identifying outcomes and impact, indicates that there is still work to do to bring strategic communication into alignment with contemporary management strategy, and identifies some of the ways that this can be operationalized.

\section{Methodology}

The following presents a critical analysis of strategic communication as revealed in evaluation models on the basis that such models provide systematic overviews of the key steps in strategic public communication practice from the setting of communication objectives to the identification of intended outcomes and impact. Pawson and Tilley $(1997,2001)$, who developed what is called 'realist evaluation', which will be examined along with other evaluation theories in the following section, say the key question in evaluation is 'what works in which circumstances and for whom?' rather than merely 'does it work? (as cited in Better Evaluation 2016, para. 2). Thus, evaluation models provide insights into how strategic communication is operationalized. Specifically, they identify what is intended to be done to whom and whose interests are served by strategic communication. In that sense, the design and use of evaluation models reflect intent (planning) as well as results. In short, evaluation models and the practices they inform provide insights into the underlying logic of strategic communication. Therefore, evaluation models are 
an ideal 'window' through which to observe the concepts and principles applied in practice and the real but often hidden motives and intentions that shape the field.

\section{Methods}

This study critically examined 20 widely discussed and promoted models that identify the recommended stages, steps, and processes for planning, evaluating, and reporting organizationpublic communication that is increasingly referred to as strategic communication. The research methods used included:

1. Content analysis of models and their accompanying guidelines and instructions; and

2. Interviews with the architects and protagonists of a number of the models in both the academy and industry organizations such as the International Association for Measurement and Evaluation of Communication (AMEC) ${ }^{2}$.

\section{Sample}

The sample of evaluation models was obtained from an extensive review of literature on evaluation of public relations and strategic corporate, government, and organizational communication published between the early 1980s and 2016. Three 'classic' models for evaluation that are widely cited in PR and communication management literature and three of the most recent models promoted by industry and professional bodies were selected for analysis. The models selected represent theory and practice in North America, the UK, continental Europe, and Australia, as well as other regions to the extent that Western models are influential or 'colonizing'. Interviews were conducted with the architects of a number of both classic and contemporary models as part gaining an understanding of their rationale and the thinking that informed them.

\section{Evaluation theory}

Evaluation theory for strategic communication is grounded in and derived from theory of change and program theory, which were developed in the 1970s and 1980s in the field of public administration by (in chronological order) Suchman (1967), Weiss (1972), Wholey (1970, 1979, 1983, 1987), Bennett (1976), Chen and Rossi (1983), Bickman (1987), Lipsey (1993), as well as others. Initially theory of change and program theory, incorporating program theory evaluation (PTE) and the use of program logic models, were applied to evaluating human service programs such as the delivery of social services and health campaigns, before the principles were taken up in a number of other fields ranging from agricultural programs to large construction projects. Rossi, Lipsey, and Freeman say that program evaluation based on program theory and theory of change is "useful in virtually all spheres of activity in which issues are raised about the effectiveness of organized social action" and specifically note its relevance for advertising, marketing, and other communication activities (2004, p. 6).

\section{Program logic models}

The various stages and elements of program theory are commonly explicated in program logic models, a graphic illustration of the processes in a program from setting objectives and preprogram planning to measuring its outcomes and impact (Wholey, 1979). Many evaluation models used in strategic communication today can be traced back to early program logic models used in public administration and organizational and international development, although considerable variation exists in evaluation of strategic communication.

Widely used examples of program logic models for planning and evaluation are those of the Kellogg Foundation (1998/2004) and the University of Wisconsin Extension program UWEX 
model (Taylor-Power \& Henert, 2008, p. 4). While the Kellogg Foundation model breaks programs into five stages - inputs, activities, outputs, outcomes, and impact - some models identify up to seven stages in programs by breaking outcomes into short, medium, and long-term (see Figure 1).

Figure 1. The University of Wisconsin Extension Program (UWEX) program logic model (Taylor-Power \& Henert, 2008, p. 4).

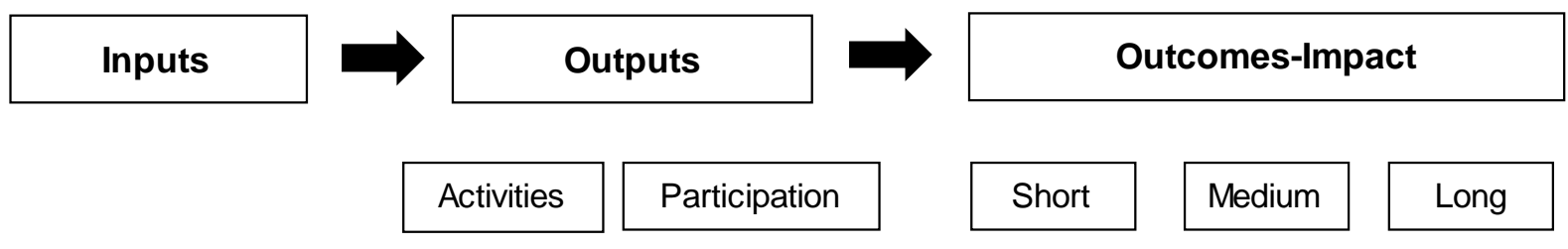

The UWEX Developing a Logic Model: Teaching and Training Guide notes that "many variations and types of logic models exist” (Taylor-Power \& Henert, 2008, p. 2). The Kellogg Foundation similarly says "there is no one best logic model” (2004, p. 13). However, there are a number of common concepts and principles in program logic models for evaluation. As well as identifying the 'logic' of programs (i.e., which inputs and activities lead to the desired outcomes and impact), all program evaluation models emphasize:

1. Planning begins with identification of objectives;

2. Evaluation includes formative research conducted before activities are undertaken to identify existing conditions (e.g., audience awareness, attitudes, interests and needs in the case of communication), establishes benchmarks for later comparison, and informs strategy, followed by process and summative research during and after activities are undertaken;

3. Programs should ultimately achieve and be evaluated in terms of outcomes and impact - not simply in terms of activities and outputs.

\section{Realist evaluation}

What is termed realist evaluation adds two further key considerations to evaluation relevant to this discussion. Sometimes referred to as 'realistic' evaluation - a term that is mostly rejected because it suggests a narrow and simplistic approach focussed on practicality ${ }^{3}$ - realist evaluation specifically turns attention to stakeholders and social context. Realist evaluation (RE) places emphasis on the context of programs and the interests of all 'actors' using contextmechanism-outcome (CMO) analysis as a methodology for evaluation (Better Evaluation, 2016; Salter \& Kothari, 2014). This approach is contrasted with commonly used communication evaluation models in the following section.

\section{Evaluation of strategic communication}

The history and development of a range of evaluation models in public relations, corporate communication, government communication, and other strategic communication fields of practice have been widely discussed and are not within the scope of this analysis (e.g., see Likely and Watson, 2014 and Macnamara and Likely, 2017). Macnamara (2018) has identified 30 evaluation frameworks and models used across the strategic communication fields of advertising; public relations; corporate, government, and organizational communication; and specialist fields such as health communication. 
The following analysis examines six widely used evaluation models for strategic communication in the context of how they inform strategic communication and how they identify success and effectiveness.

\section{Evaluation models for communication - what they tell us about strategy}

\section{The PII Model}

One of the earliest evaluation models promoted for public relations in a widely-used textbook, the Planning, Implementation, Impact (PII) model (Cutlip, Center, \& Broom, 1985), identified a range of impacts including "social and cultural change" (see Figure 2). This suggests a concern for society and broad impacts on culture. However, in successive editions the authors make it clear that the social and cultural changes referred to are those intended and planned by the organization to achieve its objectives. For example, in its single mention of listening to stakeholders and publics, the 2009 edition of Cutlip \& Center's Effective Public Relations describes the process as part of "systematic" and "scientific research" necessary for achieving the organization's goals (Broom, 2009, pp. 271-272). Citing the functionalist communication model of Schramm (1971), the 2013 edition says that "feedback [a key part of evaluation] tells the listener how his [sic] message is being received” (Broom \& Sha, 2013, p. 243). This concept of evaluation clearly positions communication as a process of getting the organization's messages across (i.e., persuasion), rather a process of mutuality, adaptation, and two-way interaction.

Figure 2. The planning, implementation, impact (PII) model (Cutlip, Center \& Broom, 1985).

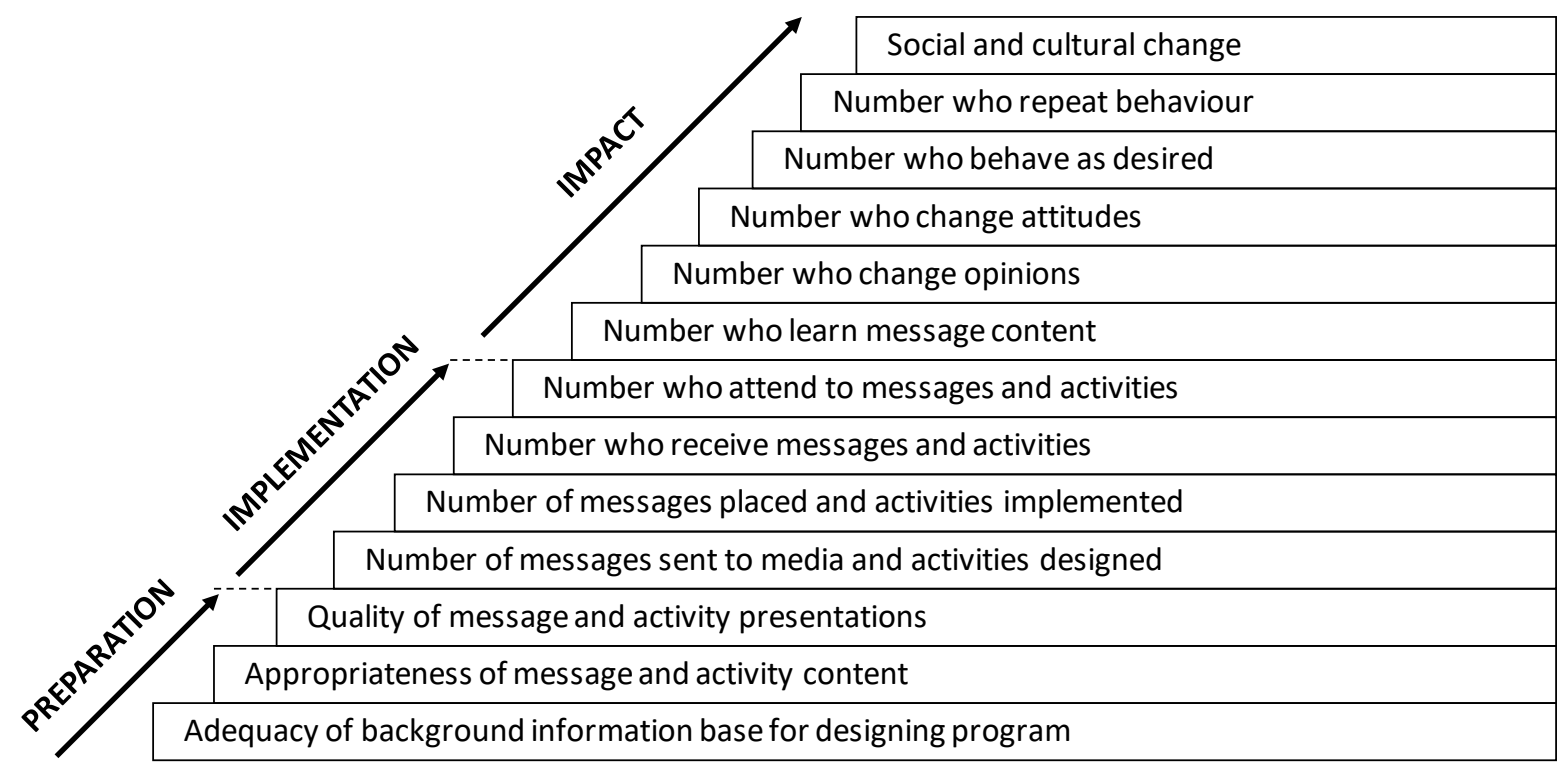

\section{The PR 'effectiveness yardstick'}

Another early and widely used model of evaluation in the public relations field is the PR 'Effectiveness Yardstick', also a vertically arranged program logic model, developed by Lindenmann (1993). Lindenmann named the stages "basic", which he described as outputs; "intermediate", which he described as outgrowths, thus introducing a new term to the evaluation lexicon, and "advanced", which he described as outcomes. Lindenmann's model usefully identifies a number of specific steps within the stages such as reception, awareness, comprehension, retention, opinion change, attitude change, and behaviour change. However, the accompanying text explaining the model makes it clear that the opinion, attitude, and behaviour 
change to be evaluated are those sought by the organization in line with its objectives. Lindenmann acknowledges that he was influenced by functionalist and behaviourist psychology saying:

The theory behind the model came primarily from well-known communications scholars, especially William J. McGuire, Wilbur Schramm, Everett Rogers, Charles R. Wright, Elihu Katz ... and Jim Grunig. I was especially taken with the excellent essay of McGuire, 'Persuasion, resistance and attitude change' which appeared in the 1973 Handbook of Communication. McGuire had a matrix that he used in his essay, which I relied on heavily to explain the Yardstick model. The matrix and the arguments that McGuire presented led me to create the stages in the model the way I did. (W. Lindenmann, personal communication, January 18, 2016)

Figure 3. The PR effectiveness yardstick (Lindenmann, 1993).
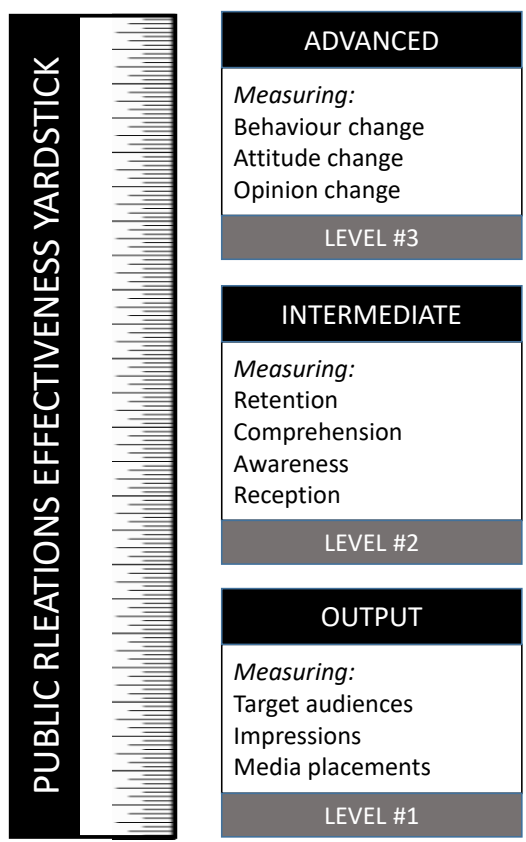

OUTCOMES

OUTGROWTHS

OUTPUTS

\section{The 'communication controlling' model}

In Europe a number of communication industry organizations including the Deutsche Public Relations Gesellschaft (DPRG) and Gesellschaft Public Relations Agenturen (GPRA) in Germany, working in partnership with academics and management organizations, produced the 'communication controlling' model for planning and evaluating strategic communication (DPRG/ICV, 2009 [German]; Huhn, Sass, \& Storck, 2011, p. 13 (English]). As shown in Figure 4 , this was largely based on program logic models, identifying four stages of communication as input, output, outcome, and outflow. The communication controlling model lists 'opinion', 'attitudes' and 'behaviour' as outcomes of communication and, hypothetically, this could include influencing or changing the opinion, attitudes or behaviour of the organization to align with the interests of stakeholders. However, the following text in the model and accompanying descriptions make it explicitly clear that the outcomes and 'outflows' sought and evaluated are those benefitting the organization such as "brand image"; "purchase intention"; "leads"; "sales", "employee performance", "meeting financial targets", and "capital accumulation”. With its focus on sales, financial targets, and capital, the model clearly positions strategic communication as a tool of management and part of the engine of capitalism. Furthermore, the bottom sections of the model list stakeholders as the site of changes and the organization as the recipient or beneficiary of outflows (see Figure 4). The bottom panels in the model also explicitly start and conclude the evaluation process with the organization, implying its focus and primacy. 
Figure 4. The 'communication controlling' model of planning and evaluation (Huhn, Sass, \& Storck, 2011).

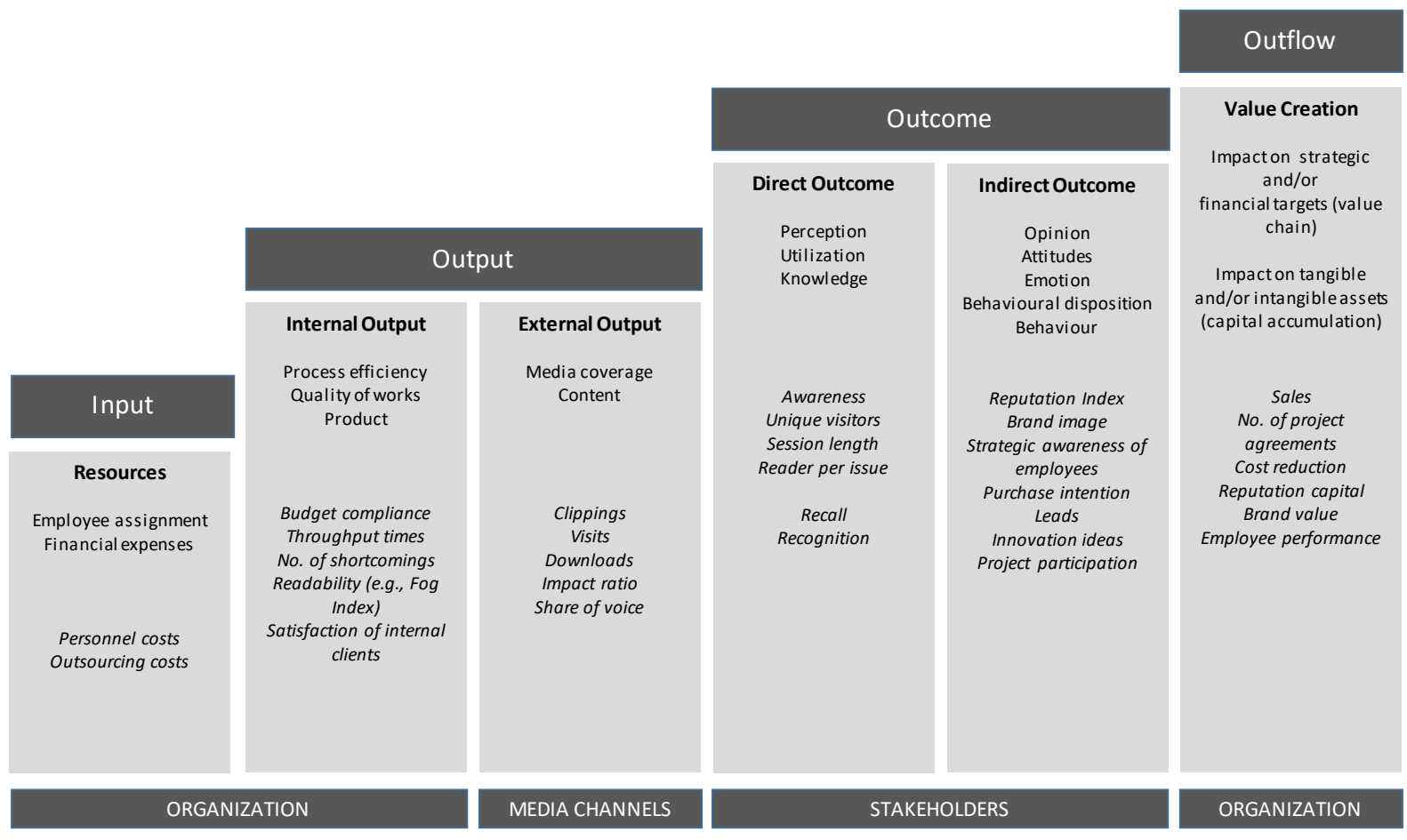

\section{The European Commission model of evaluation}

The European Commission Directorate-General for Communications model of evaluation, which is recommended for use in all strategic communication across the 28 member countries of the European Union, even more explicitly shows outcomes flowing to meet the communication objectives and the political priorities of the organization (as indicated by the arrows). There is no recognition of the outcomes for stakeholders and society other than those intended by the organization. Another feature of this model (see Figure 5) is that it specifically identifies 'communication objectives' as flowing from and serving the organization's priorities, with all activities, outputs, outtakes, and outcomes linked to the organization's objectives. There is no articulated step in the model for the interests of stakeholders and citizens to inform the communication objectives or activities of the organization. Thus, this model is shown to be entirely organization-centric, as the results of all activities are shown to flow 'upwards' to serve the "political priorities" of the European Commission (EC).

\section{The UK Government Communication Service model}

The UK Government is recognized as progressive in the design and implementation of evaluation of strategic communication within its 17 national government departments and several hundred arm's length bodies (agencies), which is coordinated by the Government Communication Service (GCS) co-headquartered in the Cabinet Office and the Prime Minister's office in Number 10 Downing Street. The GCS introduced its latest evaluation model in early 2016 (see Figure 6). As with the EC model, this shows communication objectives directly flowing from and thus designed to serve the organization's or policy objectives of the government and, again, all inputs, outputs, outtakes, and outcomes are planned to align with the organizational and subsidiary communication objectives. An even more explicit indicator or organization-centricity in this model is that the final stage and goal of communication programs is defined specifically as “organizational impact”. Lest this be perceived as impact upon the organization, the text box under this part of the model advocates "selection of the right business KPIs to track performance 
of your integrated communication activities against your organizational goals”, thus making it very clear that organizational impact is perceived as what the organization wants, not what stakeholders or publics might want of it. Despite being designed for government communication in a democratic country, stakeholders, publics, or society are not represented or reflected at any point in this model used for planning and evaluating strategic public communication.

Figure 5. The European Commission Directorate-General for Communications model of evaluation (EC, 2015a, 2015b).

\section{0 political priorities}

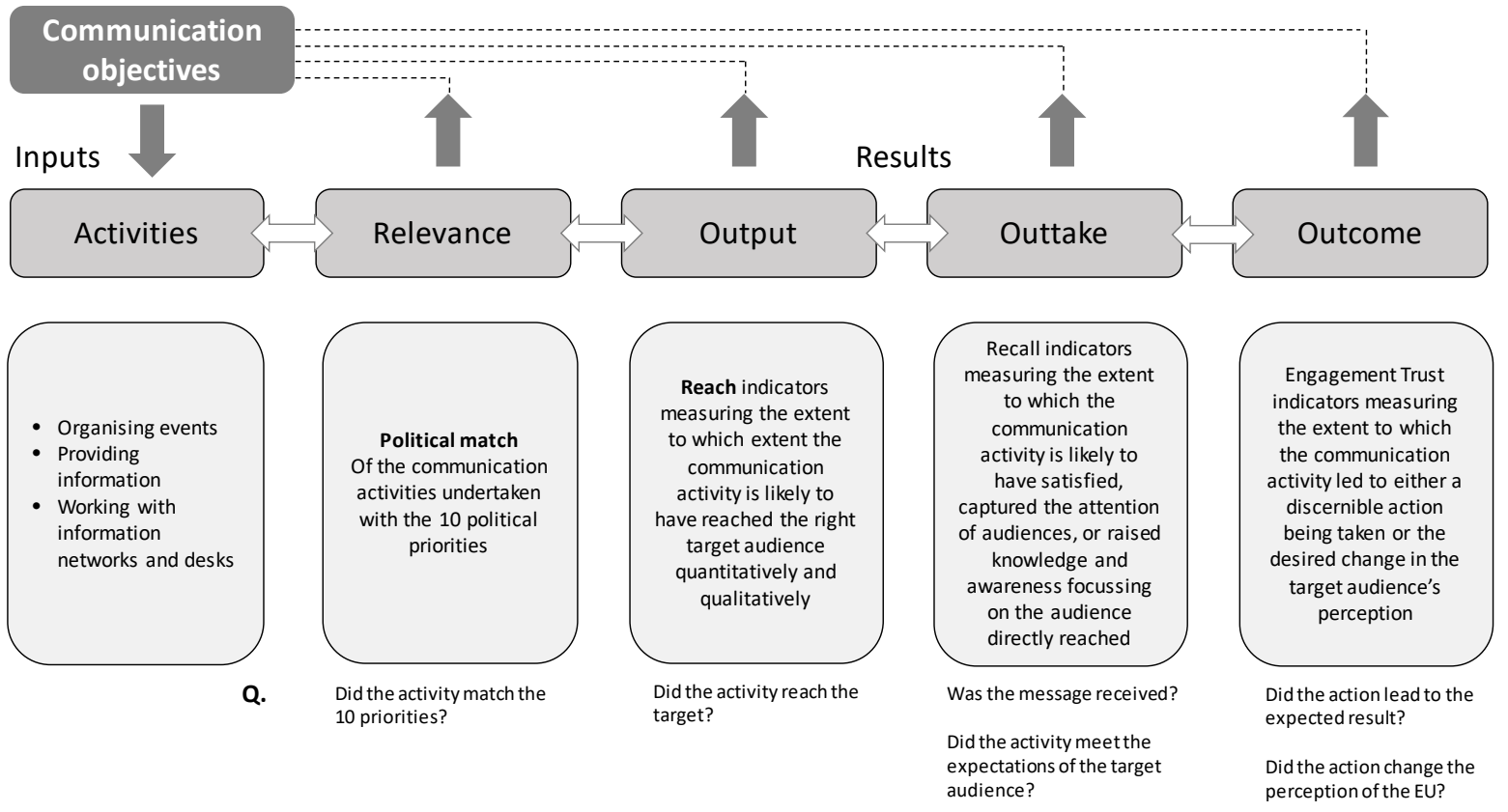

Figure 6. The UK Government Communication Service evaluation framework (GCS, 2016).

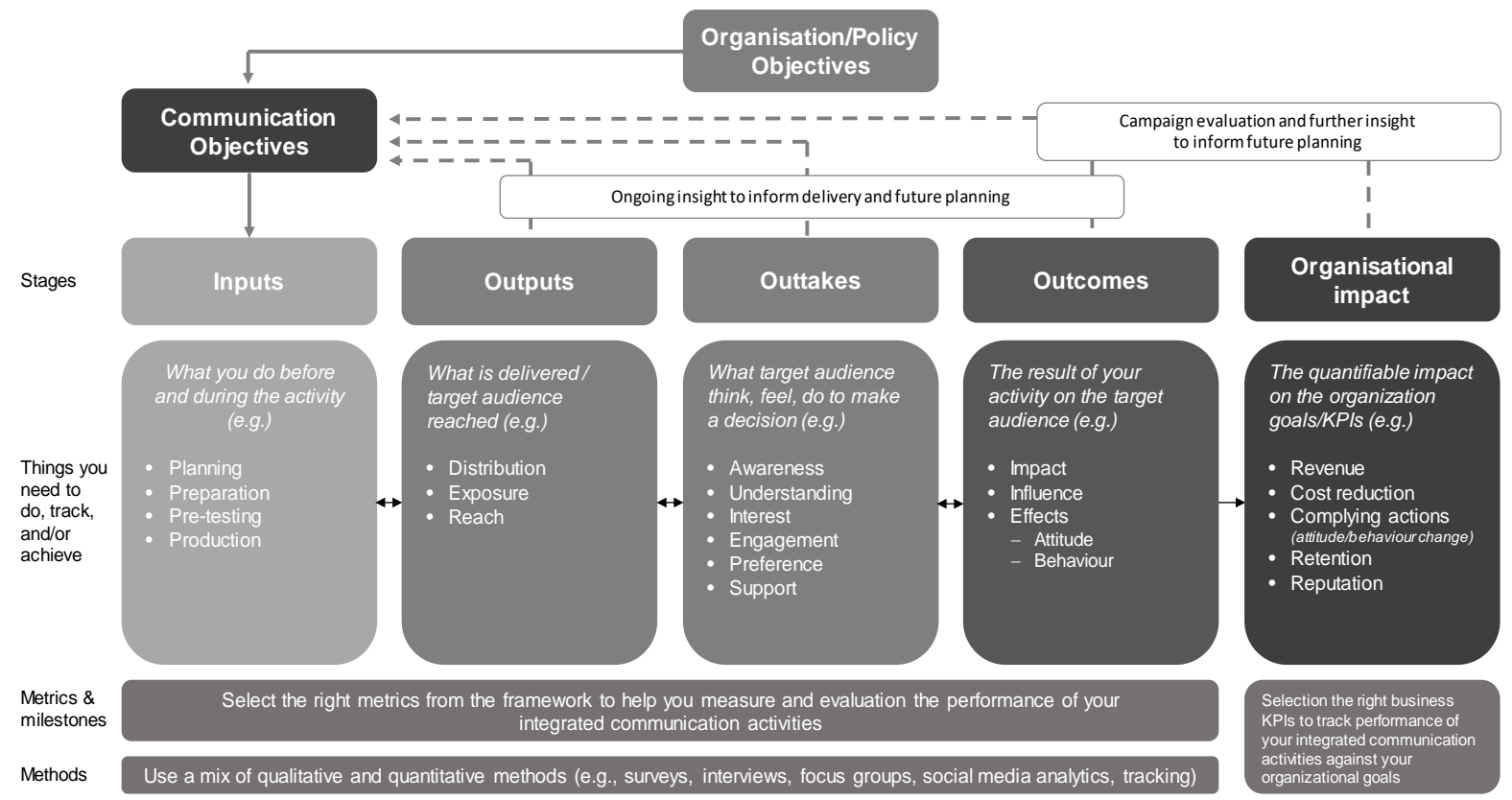


Paul Njoku, who was involved in coordinating and implementing the GCS evaluation framework while working in the UK Cabinet Office, said:

Of course we can't say it's perfect. There's always room for improvement ... But I believe we have got the fundamentals right. We have drawn on a wide range of published literature on evaluation ... and we apply social science research methodology. We also have combined that with a realistic appraisal of what evaluation can and should be done in the context of budget and other priorities. (P. Njoku, personal communication, August 19, 2016)

\section{The AMEC Integrated Evaluation Framework}

The sixth model examined is the latest so-called Integrated Evaluation Framework developed and published by the International Association for Measurement and Evaluation of Communication (AMEC). While incorporating many progressive elements such as offering an interactive online tool rather than a static model, this framework reflects most of the same features and limitations as the other models examined. The AMEC Integrated Evaluation Framework (see Figure 7) describes strategic communication in six stages: inputs, activities, outputs, out-takes, outcomes, and organizational impact. Preceding these stages, the model/framework emphasizes setting objectives as the first step (i.e., by stating 'Start here').

Figure 7. The AMEC Integrated Evaluation Framework (AMEC, 2017).

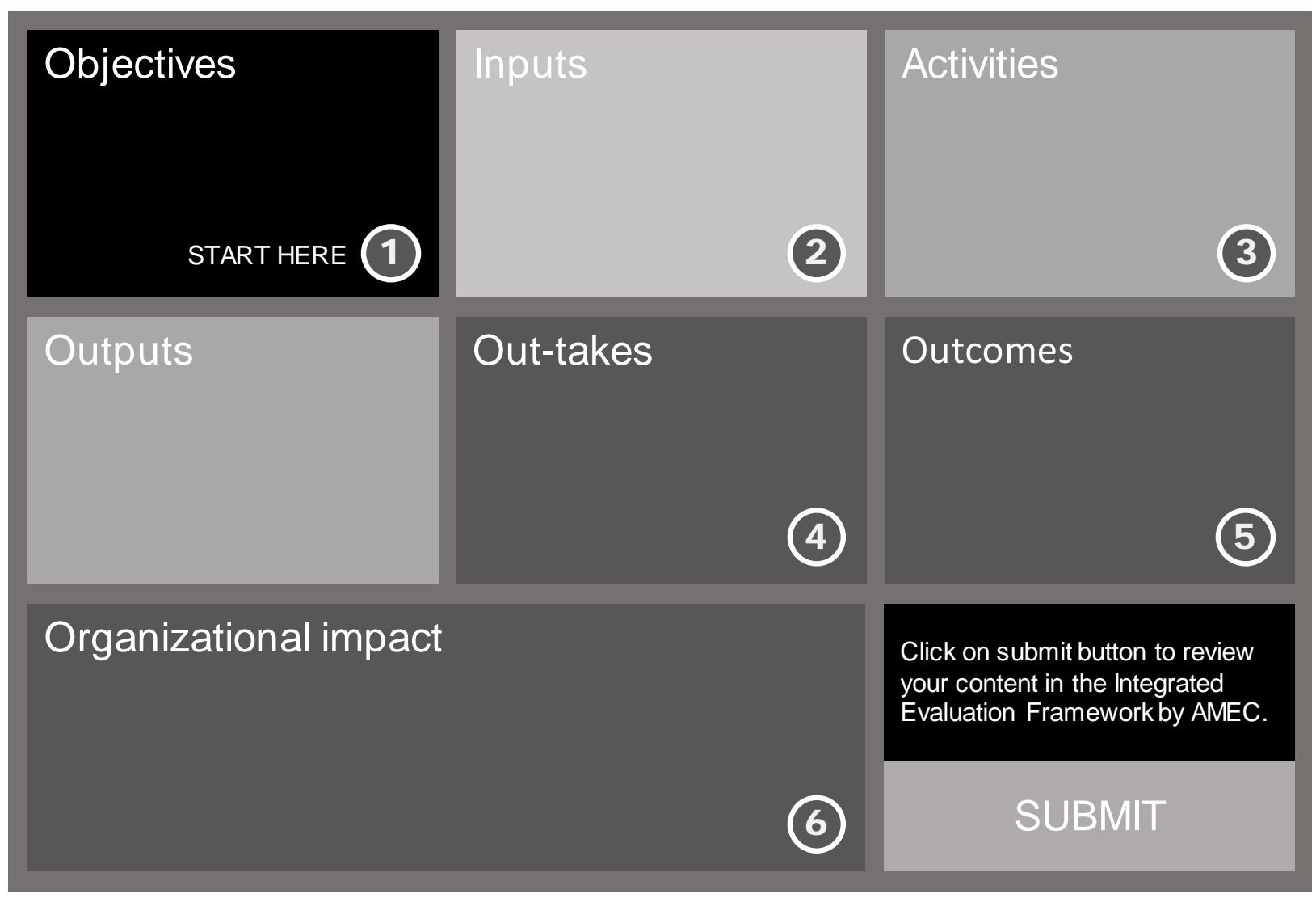

A 'pop-up' information box on the 'Objectives' part of the model explicitly states that these should include "organizational objectives" with "communications objectives" listed under the former illustrating their direct connection and subordinate relationship.

The 'pop-up' information box at the impact stage of the model does ask users to list "how has the organization been impacted during the campaign?” (AMEC, 2017). However, a further 'information' box on the interactive model gives examples of impacts to be recorded including 
"reputation improvement” (of the organization), "sales”, “donations”, and "compliance” such as the success of social marketing campaigns. 'Social goals' are noted to include improved public health and wellbeing through results such as reducing smoking - hence this model can be identified as more socially inclusive and open than the other models examined. Nevertheless, like all other models of evaluation for strategic communication, it is entirely focussed on planning and measuring what the organization wants to achieve among its stakeholders and publics.

In describing the AMEC evaluation framework, the chair of AMEC, Richard Bagnall, echoed Njoku saying:

It would be a massive claim to say that AMEC's Integrated Evaluation Framework is perfect. No doubt it can be improved still further. It's unlikely that any model of framework could ever be perfect. But we believe this is a major step forward for the communication industry and accomplishes its remit ... Importantly, we also believe that it works for organizations of all sizes with differing objectives and budgets. (R. Bagnall, personal communication, October 15, 2016)

\section{Findings and discussion}

Analysis of the latest (and one could expect most advanced) models for evaluation of strategic communication developed or endorsed by industry and professional organizations reveals at least four significant limitations and opportunities for expansion. These include:

1. Stakeholders, publics, and society are not represented in any of the models, either graphically or textually other than as recipients of information and messages and targets for persuasion and change. Models, by nature, are meant to represent all the key components and steps of a process. Thus, this omission is significant and symbolic of a one-way, top-down organization-centric notion of strategy and communication that lingers in evaluation literature;

2. It is notable that many of these models start with organizational objectives without mentioning formative research in which stakeholder interests may be identified and accommodated;

3. All models list communication objectives as solely derived from and serving organizational goals, objectives, and priorities. Some argue that this is appropriate, as discussed below. However this approach further reflects the one-way, top-down notion of communication referred to above;

4. In addition to not reflecting stakeholder, public, or societal needs, expectations, or interests, none of the models suggest evaluation of unintended outcomes and impact that can occur. For example, achieving an organization's sales objectives can result in negative impacts on consumers such as the infamous case of Nestlé's infant milk formula promotion (Sethi, 1994). Even though reporting against agreed key performance indicators (KPIs) is commonly a management requirement, a comprehensive holistic approach to evaluation should consider all outcomes and impacts of communication as part of both learning and informing future strategy.

Some argue that communication objectives must fully align to and serve organizational objectives and, therefore, strategic communication is limited to the overarching organizational strategy which may or may not include consideration of stakeholder interests - i.e., in simple terms, organizational communicators are the implementers of organizational strategy, not 
involved in its formulation and that the sole purpose of communication is to serve organizational objectives. At a fundamental level, this ignores the principles of communication as a two-way process. Furthermore, it ignores the strategic counsel role of communication practitioners, which has been identified in literature dating back to Edward Bernays' use of the term 'public relations counsel' (Bernays, 1923) and the 1948 book by Eric Goldman, The Two-way Street: The Emergence of the Public Relations Counsel (Goldman, 1948). More recently, in the first of the PR Excellence theory texts, Dozier (1992) distinguished between the roles of communication technicians and communication managers by emphasizing that the latter's role included advising management on the interests and needs of publics and societal impacts as well as serving the interest and needs of the organization. Relevant to this discussion, Hon (1997) argued that evaluation of strategic communication should support societal as well as organizational objectives. This argument was also made by Grunig (2000) and taken up in a 2001 article on PR evaluation by Gregory, who called for recognition that "public relations programmes fit within a wider organizational and societal context” (2001, p. 177). The third and major Excellence theory text advocated evaluation at (1) program level; (2) functional level (e.g., department or unit); (3) organizational level; and (4) societal level (L. Grunig, J. Grunig, \& Dozier, 2002, pp. 91-92), an approach advanced by many PR scholars since (e.g., Gregory \& Willis, 2013). As noted previously, in corporate communication literature, Cornelissen says that "strategy is about the organization and its environment" and that strategy involves "balancing the mission and vision of the organization ... with what the environment will allow or encourage it to do" (2011, p. 83).

Critical and postmodern perspectives in public relations, corporate communication, and related fields have drawn attention to this lack of focus on stakeholder and societal impact for a number of years (e.g., L'Etang, 2008; L'Etang, McKie, Snow, \& Xifra, 2015; L'Etang \& Pieczka, 1996, 2006; McKie \& Munshi, 2007). Thus, there is strong reason and impetus to support a broader two-way approach to strategic communication and to evaluation that can inform organizational strategy as well as communication strategy.

\section{Conclusions and recommendations}

Noting that evaluation models reflect the strategic intent and planning of communication through formative evaluation and setting of communication objectives, as well as the processes for measuring outcomes and impact of communication through summative evaluation, evaluation is proposed as a key area of practice requiring a 'stakeholder turn'. Specifically, there is a need for reconceptualization of evaluation of strategic communication that pays attention to the interests of stakeholders, publics, and society in setting objectives and in terms of outcomes and impacts, both intended and unintended. This can be effected in a number of ways as suggested in Figure 8 and the following recommendations.

The proposed reconceptualization of planning and evaluation illustrated in Figure 8 highlights a number of key additions to existing models and practices as follows.

1. While communication objectives must necessarily be designed to support organizational objectives, they also should take into account the needs, expectations and interests of stakeholders, publics, and society. This can be done through formative evaluation using environmental scanning including desk research, surveys, pre-testing, consultation, direct stakeholder engagement and, as management scholars Matzler et al. (2014) note, social media monitoring and analysis. 
Figure 8. Proposed new model of evaluation in development in collaboration with the Public Relations Institute of Australia, AMEC, and others.

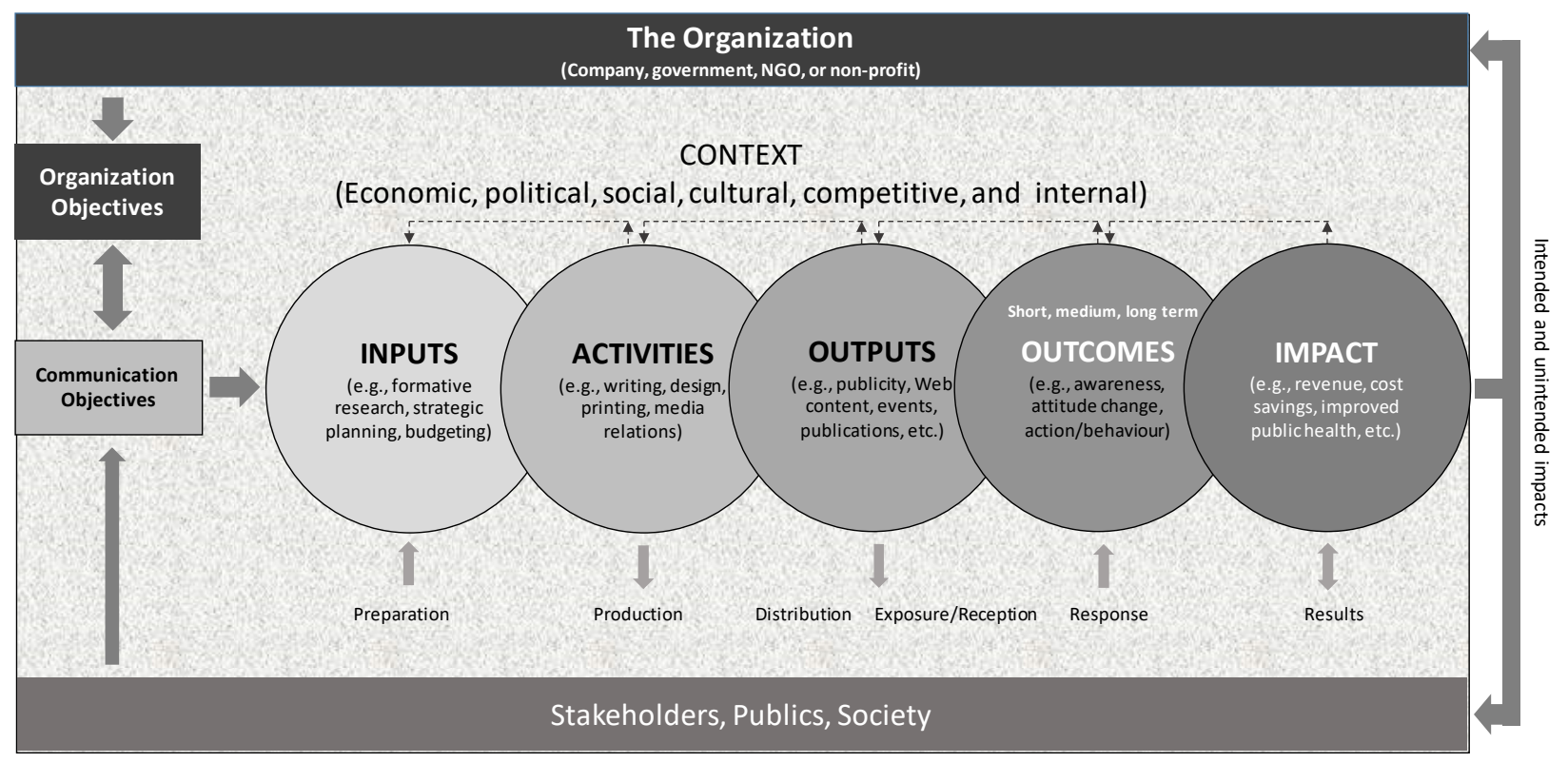

2. The entire process of planning, implementing, and evaluating strategic communication exists within a context (shown as the textured background in Figure 8). This includes social, cultural, economic, and political contexts, and it must be recognized that contexts change over time, which may necessitate adjustments in strategy. In terms of evaluation, this means that the context in which the organization and its stakeholders, publics, and society interact needs to be continuously evaluated (e.g., through environmental scanning, consultation, and ongoing stakeholder engagement).

3. While activities and outputs primarily flow from the organization to stakeholders, publics, and society during the processes of production, distribution and exposure, inputs should include information about stakeholders and publics gained through formative research and response flows from stakeholders, publics, and society to the organization (e.g., through feedback, social and market research, public consultation, complaints analysis, etc.). Evaluation models should ensure that these formative research and response mechanisms are in place and effective so that the organization is 'listening' and able to adapt its strategy if required. Despite claims of two-way communication in PR and corporate communication literature, research shows that "most organizations listen sporadically at best, often poorly, and sometimes not at all” (Macnamara, 2016, p. 236) other than instrumentally to what they want or need to know to achieve their objectives. Hence, improved organizational listening is required as part of evaluation.

4. Finally, and very importantly, impact must be recognized as bidirectional - that is, flowing to stakeholders as well as the organization - and as including unintended as well as intended impact. The pursuit of outcomes and impact desired by an organization may result in positive or negative outcomes and impact for stakeholders, publics, or society. For example, aggressive product promotion to increase corporate revenue may disadvantage consumers, which can ultimately lead to resentment and reputation damage. Political 'spin' can undermine public trust in government. Strategic communication should involve evaluation of outcomes and impact more broadly than the deliberate and immediate objectives of an organization. While some might argue that this is beyond the scope of evaluation, summative evaluation can and usually should include ex-ante surveys of key stakeholders or even more 
open-ended qualitative methods of research such as focus groups or interviews to gain feedback.

This analysis has shown that, despite a large body of evaluation literature, strategic communication as it is evolving is not well served by existing evaluation models. While existing models adequately serve to evaluate organization messaging, this focussed approach is narrow and organization-centric. A more open approach implemented through a continuous cycle of formative, process and summative evaluation can provide organizations with a dynamic feedback loop, thus informing as well as reporting the outcomes and impact of strategy. Expanded evaluation as outlined can make a major contribution to progressing strategic communication beyond early control-focussed approaches to a function that supports customercentricity in businesses, citizen engagement and open policy making for public sector organizations, collaboration, agility, and other contemporary management approaches.

Finally, such an approach recognizes the realities of the modern communication environment in which two-way communication is not only increasingly expected and demanded by stakeholders and publics, but is also more ethical. It takes into account the view that organizations have an obligation to stakeholders and society. Organizations' effectiveness in listening to and responding to these broader perspectives is therefore key to operationalizing corporate social responsibility and maintaining a 'licence to operate'.

\section{References}

Aarts, N. (2009). Een gesprek zonder einde [A never ending conversation]. Amsterdam: Vosspuspers.

Aarts, N., \& Van Woerkum, C. (2008). Strategische communicatie [Strategic communication]. Assen, Holland: Van Gorcum.

AMEC (Association for Measurement and Evaluation of Communication). (2017). Integrated evaluation framework. London, UK: Author. Retrieved from http://amecorg.com/amecframework

Bakhtin, M. (1986). Speech genres and other late essays (C. Emerson \& M. Holquist, Eds., V. McGee, Trans.). Austin, TX: University of Texas Press. (Original work published 1979)

Bauman, A., \& Nutbeam, D. (2014). Evaluation in a nutshell: A practical guide to the evaluation of health promotion programs (2nd ed.). North Ryde, NSW: McGraw-Hill.

Bennett, C. (1976). Analyzing impacts of extension programs, ESC-575.Washington, DC: US Department of Agriculture Extension Service. Department of Agriculture, Extension Service.

Bentele, G. (2004). New perspectives of public relations in Europe. In B. van Ruler \& D. Verčič (Eds.), Public relations and communication management in Europe (pp. 485-496). Berlin, Germany: Mouton de Gruyter.

Bernays, E. (1923). Crystallising public opinion. New York, NY: Boni \& Liveright.

Better Evaluation. (2016). Realist evaluation [Web site]. Melbourne, Vic: Author. Retrieved from http://betterevaluation.org/approach/realist_evaluation

Bickman, L. (1987). The functions of program theory. In New Directions for Program Evaluation, 33, 5-18. San Francisco, CA: Jossey-Bass. https://doi.org/10.1002/ev.1443

Broom, G., \& Dozier, D. (1990). Using research in public relations: Applications to program management. Englewood Cliffs, NJ: Prentice-Hall.

Buber, M. (1958). I and thou (R. Smith, Trans.). New York: Scribners. (Original work published 1923, 2nd ed. 1987)

Chen, H., \& Rossi, P. (1983). Evaluating with sense: The theory-driven approach. Evaluation Review, 7(3), 283-302. https://doi.org/10.1177/0193841X8300700301

Cornelissen, J. (2011). Corporate communication: A guide to theory and practice (3rd ed.). Thousand Oaks, CA: Sage.

Craig, R. (2006). Communication as a practice. In G. Shepherd, G. St John, \& T. Striphas (Eds.), Communication as ... Perspectives on Theory (pp. 38-49). Thousand Oaks, CA: Sage.

Cutlip, M., Center, A., \& Broom, G. (1985). Effective public relations (6th ed.). Englewood Cliffs, NJ: Prentice-Hall. 
Deetz, S. (1992). Democracy in an age of corporate colonization: Developments in communication and the politics of everyday life. New York, NY: State University of New York.

Denning, S. (2016). How to make the whole organization 'agile'. Strategy \& Leadership, 44(4), pp.1017. https://doi.org/10.1108/SL-06-2016-0043

DPRG/ICV (Deutsche Public Relations Gesellschaft and International Controller Verein). (2009). DPRG/ICV framework for communication controlling. Retrieved from http://www.communicationcontrolling.de/index.php?id=280\&type=98\&tx_ttnews[tt_news]=\&L=3

Dulek, R., \& Campbell, K. (2015). On the dark side of strategic communication. International Journal of Business Communication, 52(1), 122-142. doi.org/10.1177/2329488414560107

EC (European Commission). (2015a). Better regulation guidelines. Brussels, Belgium: Author. Retrieved from http://ec.europa.eu/smart-regulation/guidelines/toc_guide_en.htm

EC (European Commission). (2015b). External communication network code of conduct on measurement and evaluation of communication activities. Brussels, Belgium: Author. Retrieved from http://ec.europa.eu/dgs/communication/about/evaluation/documents/code-of-conductmeasurement-evaluation-communication-activities_en.pdf

Ehling, W. (1992). Estimating the value of public relations and communication to an organisation. In J. Grunig (Ed.), Excellence in public relations and communication management (pp. 617-638). Hillsdale, NJ: Lawrence Erlbaum.

Falkheimer, J., \& Heide, M. (2011, May). Participatory strategic communication: From one- and twoway communication to participatory communication through social media. Paper presented at the International Communication Association 2011 pre-conference, 'Strategic communication - A concept at the center of applied communications', Boston, MA.

Falkheimer, J., \& Heide, M. (2015). Strategic communication in participatory culture: From one- and two-way communication to participatory communication through social media. In D. Holtzhausen \& A. Zerfass (Eds.), The Routledge handbook of strategic communication (pp. 337-350). New York, NY: Routledge.

Fawkes, J. (2015). Public relations ethics and professionalism: The shadow of excellence. Abingdon, Oxon., UK: Routledge.

Flynn, T., Gregory, A., \& Valin, J. (2008). What is public relations? [Web site]. Ontario, Canada: Canadian Public Relations Society. Retrieved from http://www.cprs.ca/Aboutus/whatisPR.aspx

Foss, S., \& Griffin, C. (1995). Beyond persuasion: A proposal for an invitational rhetoric. Communication Monographs, 62, 2-18.

Gadamer, H. (1989). Truth and method (2nd ed., J. Weinsheimer \& D. Marshall, Trans.). New York, NY: Crossroad. (Original work published 1960)

GCS (Government Communication Service). (2016). GCS evaluation framework. London, UK: Cabinet Office. Retrieved from https://gcs.civilservice.gov.uk/wp-content/uploads/2015/11/GCS_GCSEvaluation-framework_A4-_191115.pdf

Goldman, E. (1948). Two-way street: The emergence of the public relations counsel. Boston, MA: Bellman Publishing Company.

Gregory, A. (2001). Public relations and evaluation: Does the reality match the rhetoric. Journal of Marketing Communications, 7, 171-189. https://doi.org/10.1080/13527260122625

Gregory, A., \& Watson, T. (2008). Defining the gap between research and practice in public relations programme evaluation: Towards a new research agenda. Journal of Marketing Communications, 24(5), 337-350. https://doi.org/10.1080/13527260701869098

Gregory, A., \& Willis, P. (2013). Strategic public relations leadership. London, UK: Routledge.

Grunig, J. (2000) Collectivism, collaboration, and societal corporatism as core professional values in public relations. Journal of Public Relations Research, 12(1), 23-48. https://doi.org/10.1207/S1532754XJPRR1201_3

Grunig, L., Grunig J., \& Dozier, D. (2002). Excellent organizations and effective organizations: A study of communication management in three countries. Mahwah, NJ: Lawrence Erlbaum.

Hallahan, K., Holtzhausen, D., van Ruler, B., Verčič, D., \& Sriramesh, K. (2007). Defining strategic communication, International Journal of Strategic Communication, 1(1), 3-35.

Heath, R. (2001). A rhetorical enactment rationale for public relations: The good organisation communicating well. In R. Heath (Ed.), Handbook of public relations (pp. 31-50). Thousand Oaks, CA: Sage.

Heath, R. (2006). A rhetorical theory approach to issues. In C. Botan \& V. Hazelton (Eds.), Public relations theory II (pp. 63-99). Mahwah, NJ: Lawrence Erlbaum. 
Heath, R. (2009). The rhetorical tradition: Wrangle in the marketplace. In R. Heath, E. Toth \& D. Waymer (Eds.), Rhetorical and critical approaches to public relations II (pp. 17-47). New York, NY: Routledge.

Holtzhausen D. (2005). Public relations practice and political change in South Africa. Public Relations Review, 31(3), 407-416. https://doi.org/10.1016/j.pubrev.2005.05.011

Holtzhausen, D., \& Zerfass, A. (2013). Strategic Communication - Pillars and perspectives of an alternative paradigm. In A. Zerfass, L. Rademacher, \& S. Wehmeier (Eds.), Organisationskommunikation und public relations: Forschungsparadigmen und neue Perspektiven (pp. 73-94). Weisbaden, Germany: Springer.

Holtzhausen, D., \& Zerfass, A. (2015). Strategic communication: Opportunities and challenges of the research area. In D. Holtzhausen \& A. Zerfass (Eds.), The Routledge handbook of strategic communication (pp. 3-17). New York, NY: Routledge.

Hon, L. (1997) What have you done for me lately? Exploring effectiveness in public relations. Journal of Public Relations Research, 9(1), 1-30. https://doi.org/10.1207/s1532754xjprr0901_01

Huhn, J., Sass, J., \& Storck, C. (2011). Communication controlling: How to maximize and demonstrate the value creation through communication. Berlin, Germany: German Public Relations Association (DPRG). http://www.communicationcontrolling.de/fileadmin/communicationcontrolling/sonst_files/Position_ paper_DPRG_ICV_2011_english.pdf

Kellogg Foundation. (1998/2004). Logic model development guide. Battle Creek, MI: Author. Retrieved from https://www.wkkf.org/resource-directory/resource/2006/02/wk-kellogg-foundation-logicmodel-development-guide

Kent, M., \& Taylor, M. (2002). Toward a dialogic theory of public relations. Public Relations Review, 28(1), 21-37. https://doi.org/10.1016/S0363-8111(02)00108-X

King, C. (2010). Emergent communication strategies. International Journal of Strategic Communication, 4(1), 19-38. https://doi.org/10.1080/15531180903415814

Knowlton, L. \& Phillips, C. (2013). The logic model guidebook: Better strategies for great results (2nd ed.). Thousand Oaks, CA: Sage.

Ledingham, J. (2006). Relationship management: A general theory of public relations. In C. Botan \& V. Hazelton (Eds.), Public relations theory II (pp. 465-483). Mahwah, NJ: Lawrence Erlbaum.

Ledingham, J., \& Bruning, S. (1998). Relationship management and public relations: Dimensions of an organisation-public relationship. Public Relations Review, 24(1), 55-65. https://doi.org/10.1016/S0363-8111(98)80020-9

Ledingham, J., \& Bruning, S. (Eds.). (2000). Public relations as relationship management: A relational approach to the study and practice of public relations. Mahwah, NJ: Lawrence Erlbaum.

L'Etang, J. (2008). Public relations: Concepts, practice and critique. London and Thousand Oaks, CA: Sage.

L’Etang, J., McKie, D., Snow, N., \& Xifra, J. (2015). The Routledge handbook of critical public relations. London, UK: Routledge.

L’Etang, J., \& Pieczka, M. (1996). Critical perspectives in public relations. London: International Thomson Business Press.

L’Etang, J., \& Pieczka, M. (2006). Public relations - critical debates and contemporary practice. Mahwah, NJ: Lawrence Erlbaum Associates.

Likely, F., \& Watson, T. (2013). Measuring the edifice: Public relations measurement and evaluation practice over the course of 40 years. In J. Sriramesh, A. Zerfass, \& J. Kim (Eds.), Public relations and communication management: Current trends and emerging topics (pp. 143-162). New York, NY: Routledge.

Lindenman, W. (1993). An 'effectiveness yardstick' to measure public relations success. Public Relations Quarterly, 38(1), 7-9.

Lipsey, M. (1993). Theory as method: Small theories of treatments. New Directions for Program Evaluation, 57, 5-38. https://doi.org/10.1002/ev.1637

Littlejohn, S., \& Foss, K. (2008). Theories of human communication (9th ed.). Belmont, CA: ThomsonWadsworth.

Lukaszewski, J. (2001). How to develop the mind of a strategist, Part 3. IABC Communication World, 18(3), 13-15. 
Macnamara, J. (2015). Overcoming the measurement and evaluation deadlock: A new approach and model. Journal of Communication Management, 19(4), 371-387. https://doi.org/10.1108/JCOM-042014-0020

Macnamara, J. (2016). Organizational listening: The missing essential in public communication. New York, NY: Peter Lang.

Macnamara, J. (2018). Evaluating public communication: Exploring new models, standards, and best practice. Abingdon, UK: Routledge.

Macnamara, J., \& Likely, F. (2017). Revisiting the disciplinary home of evaluation: New perspectives to inform PR evaluation standards. Research Journal of the Institute for Public Relations, 2(2), 121. Retrieved from http://www.instituteforpr.org/research-journal

Matzler, K., Füller, J., Hutter, K., Hautz, J., \& Stieger, D. (2014). Open strategy: Towards a research agenda. Social Science Research Network. Retrieved from https://ssrn.com/abstract=2416937 or http://dx.doi.org/10.2139/ssrn.2416937

McKie, D., \& Munshi, D. (2007). Reconfiguring public relations: Equity, ecology and enterprise. London, UK: Routledge.

Mintzberg, H. (1978). Patterns in strategy formation. Management Science, 24(9), 231-255. https://doi.org/10.1287/mnsc.24.9.934

Mintzberg, H. (1979). The structure of organisations. Englewood Cliffs, NJ: Prentice Hall.

Mintzberg, H., \& Waters, J. (1985). Of strategies, deliberate and emergent. Strategic Management Journal, 6(2), 257-272. https://doi.org/10.1002/smj.4250060306

Mirabeau, L., \& Maguire, S. (2014). From autonomous strategic behaviour to emergent strategy. Strategic Management Journal, 35(8), 1202-1229. https://doi.org/10.1002/smj.2149

Moran, A. (2015). Managing agile: Strategy, implementation, organization and people. Berlin, Germany: Springer.

Murphy, P. (2015). Contextual Distortion: Strategic communication versus the contextual nature or nearly everything. In D. Holtzhausen \& A. Zerfass (Eds.), The Routledge handbook of strategic communication (pp. 113-126). New York, NY: Routledge.

Palmatier, R. (2008). Relationship marketing. Cambridge, MA: Marketing Science Institute.

Pavlik, J. (1987), Public relations: What research tells us. Newbury Park, CA: Sage.

Pawson, R. (2006). Evidence-based policy: A realist perspective. Thousand Oaks, CA: Sage

Pawson, R. (2013). The science of evaluation: A realist manifesto. Thousand Oaks, CA: Sage

Pawson, R., \& Tilley, N. (1997). Realistic evaluation. London, UK: Sage.

Pawson, R., \& Tilley, N. (2001). Realistic evaluation bloodlines. American Journal of Evaluation, 22, 317-324. https://doi.org/10.1177/109821400102200305

Pawson, R., \& Tilley, N. (2004). Realist evaluation. Paper funded by the UK Cabinet Office. Retrieved from http://www.communitymatters.com.au/RE_chapter.pdf

Perrow, C. (1992). Organizational theorists in a society of organizations. International Sociology, 7(3), 371-379. https://doi.org/10.1177/026858092007003008

Peters, T. (1986). What gets measured gets done. Tom Peters’ Writing [Web log]. Retrieved from http://tompeters.com/columns/what-gets-measured-gets-done

Peters, T., \& Waterman, R. (1982). In search of excellence: Lessons from America's best-run companies. New York, NY: Harper Collins.

Rossi, P., Lipsey, M., \& Freeman, H. (2004). Evaluation: A systematic approach (7th ed.). Thousand Oaks, CA: Sage.

Sethi, S. (1994). Multinational corporations and the impact of public advocacy on corporate strategy: Nestlé and the infant formula controversy. Journal of International Business Studies, 25(3), 658660. https://doi.org/10.1057/jibs.1994.41

Suchman, E. (1967). Evaluative research: Principles and practice in public service and social action programs. New York, NY: Russell Sage Foundation.

Schendel, D., \& Hofer, C. (1979) Introduction. In D. Schendel \& C. Hofer (Eds.), Strategic management (pp. 1-22). Boston, MA: Little, Brown.

Schneider, M. (2015). US public diplomacy since 9-11: The challenges of integration. In G. Golan, S. Yang, \& D. Kinsey (Eds.), International public relations and public diplomacy: Communication and engagement (pp. 15-36). New York, NY: Peter Lang

Schreyoegg, G., \& Steinmann, H. (1987). Strategic control: A new perspective. Academy of Management Review, 12(1), 91-103. http://dx.doi.org/10.2307/257996 
Shannon, C., \& Weaver, W. (1949). The mathematical theory of communication. Urbana, IL: University of Illinois.

Sriramesh, K. (2009). Introduction. In K. Sriramesh \& D. Verčič (Eds.), The global public relations handbook: Theory, research, and practice (rev. ed., pp. xxxii-xxxvii). Abingdon, UK: Routledge.

Taylor, M., \& Kent, M. (2014). Dialogic engagement: Clarifying foundational concepts. Journal of Public Relations Research, 26(5), 384-398.

Taylor-Power, E.,\& Henert, E. (2008). Developing a logic model: Teaching and training guide. Madison, WI: University of Wisconsin-Extension Program. Retrieved from https://fyi.uwex.edu/programdevelopment/files/2016/03/lmguidecomplete.pdf

Thompson, A., Peteraf, M., Gamble, J., \& Strickland, A. (2013). Crafting and executing strategy: The quest for competitive advantage (19th ed.). New York, NY: McGraw-Hill-Irwin.

Torp, S. (2015). The strategic turn in communication science: On the history and role of strategy in science from ancient Greece until the present day. In D. Holtzhausen \& A. Zerfass (Eds.), The Routledge handbook of strategic communication (pp. 34-52). New York, NY: Routledge.

Valente, T. (2001). Evaluating communication campaigns. In R. Rice \& C. Atkin (Eds.), Public communication campaigns (3rd ed., pp. 105-124). Thousand Oaks, CA: Sage.

van Ruler, B. (2016). Public relations: Too little emphasis on communication. Communication Management Review, 1(1), 6-27. https://doi.org/10.22522/cmr20160101

van Ruler, B., \& Verčič, D. (2004). Overview of public relations and communication management in Europe. In B. van Ruler \& D. Verčič (Eds.), Public relations and communication management in Europe (pp. 1-11). New York, NY: Mouton de Gruyter.

Weiss, C. (1972). Evaluative research: Methods of assessing program effectiveness. Englewood Cliffs, NJ: Prentice Hall.

Wholey, J. (1970). Federal evaluation policy. Washington, DC: Urban Institute Press.

Wholey, J. (1979). Evaluation: Promise and performance. Washington, DC: Urban Institute Press.

Wholey, J. (1983). Evaluation and effective public management. Boston, MA: Little Brown \& Co.

Wholey, J. (1987). Evaluability assessment: Developing program theory. New Directions for Program Evaluation, 33, 77-92. https://doi.org/10.1002/ev.1447

Wiley Blackwell. (2017). Contributors notes: The international encylopedia of strategic communication. Hoboken, NJ: Wiley Blackwell.

1 While this adage is often attributed to Tom Peters and used in his recent writing, in the popular book, In Search of Excellence written with Robert Waterman, the quote is attributed to organisational theorist Mason Haire (Peters \& Waterman 1982, p. 268).

2 The International Association for Measurement and Evaluation of Communication (AMEC) launched a new evaluation framework at its international summit on measurement in June 2016 based on wide consultation with academics and industry.

3 The book that first outlined this approach was titled Realistic Evaluation (Pawson \& Tilley, 1997), but subsequently the authors settled on the term realist evaluation "because it has become the preferred nomenclature of other authors" (Pawson \& Tilley, 2004, p. 3). 